Volume 4, Issue 1 Janaury-March 2019, Pages: 276, DOI: http://dx.doi.org/10.19082/ah276

\title{
DESIGN OF NOVEL THERAPEUTIC STRATEGIES FOR ALCOHOL ADDICTION
}

\author{
Assia Keniche ${ }^{1,2}$, Si Said Mohammed El Amine ${ }^{2}$, Joseph Kajima Mulengi ${ }^{3}$, Ibtissem Louar ${ }^{4}$ \\ keniche_assia@yahoo.fr
}

1: PhD of Bioorganic and Therapeutic Chemistry, Maghnia Center University, Tlemcen, Algeria

2: Laboratory of Organic Chemistry Natural Products and Analysis University of Tlemcen, Algeria

3: Faculté des Sciences, University of Tlemcen, Algeria

4: Université des Frères Mentouri Constantine1, Constantine, 25 000, Algeria

\section{TYPE OF ARTICLE: CONFERENCE ABSTRACT}

\begin{abstract}
Background: Baclofen ${ }^{\circledR}$ is an FDA-approved GABAB agonist, used for the treatment of spasticity since the early seventies.

Objective: The aim of this study was to synthesize a new analog of BF.

Methods: The main problem of baclofen ${ }^{\circledR}$ is that it is administered as a racemate. However, in our work we synthesize the R-(-) enantiomer. In our study, we used a stereoselective method for the synthesis of peptide analog and the study of their inclusion complex with CD, at the University of Tlemcen, Algeria in 2017.

Results: For evaluation of anti-addiction activity, we have developed a new model in vivo, and the results are that our synthetized baclofen ${ }^{\circledR}$ analogues showed an anxiolytic effect. Regarding the toxicity, our results showed that our analogues have less toxic effect than baclofen; it reduces the activity of TGO enzymes, and TGP. From a histological point of view, it has no effect on the liver structure in addition to having a protective effect against lesions liverworts induced by alcohol.

Conclusion: Our conclusion begs an open question: If baclofen ${ }^{\circledR}$ can cure any form of addiction such as smoking, alcoholism and other addictions to addictive substances, and if its beneficial effect is already proven, approved, and used as an anticraving agent in several countries in the world, why until now has the Algerian health community not used baclofen ${ }^{\circledR}$ in the treatment of numerous addictions?
\end{abstract}

KEYWORDS: Alcohol addiction, Baclofen ${ }^{\circledR}$

\footnotetext{
Abstracts of Third International Conference on Health Sciences and Medical Technologies, October 2018, Tlemcen, Algeria (ICHSMT-18)

(C) 2019 The Authors. This is an open access article under the terms of the Creative Commons Attribution-NonCommercialNoDerivs License, which permits use and distribution in any medium, provided the original work is properly cited, the use is non-commercial and no modifications or adaptations are made.
} 